15 Graham DI. Ischaemic brain damage of cerebral perfusion failure type after treatment of severe hypertension. BrMed f 1975;ii:739.

16 Jackson G, Mahon W, Pierscianowski TA, Condon J. Inappropriate antihypertensive therapy in the elderly. Lancet 1976;ii:1317-8.

17 Cove DH, Seddon M, Fletcher RF, Dukes DC. Blindness after treatment for malignant hypertension. Br Med f 1979;ii:245-6.

18 Ledingham JGG, Rajagopalan B. Cerebral complications in the treatment of accelerated hypertension. Qf Med 1979;48:25-41.

19 Pitlik S, Manor RS, Lipshitz I, Perry G, Rosenfeld J. Transient retinal ischaemia induced by nifedipine. BrMed $\mathcal{O}$ 1983;287:1845-6.

20 Phillips MS, Jones JV. Emergency treatment of high blood pressure with oral atenolol. Br Med $\mathcal{J}$ $1981 ; 283: 58$.

21 Strandgaard S, Andersen GS, Ahlgreen P, Nielsen PE. Visual disturbances and occipital brain infarct following acute, transient hypotension in hypertensive patients. Acta Med Scand infarct following
$1984 ; 216: 417-22$.

22 Russell RW, Page NGR. Critical perfusion of brain and retina. Brain 1983;106:419-34

23 Jansen PAF, Schulte BPM, Mevboom RHB, Gribnau FWJ. Antihypertensive treatment as a possible cause of stroke in the elderly. Age Ageing 1986;15:129-38.

24 World Health Organisation. Cerebrovascular diseases--prevention, treatment and rehabilitation. WHO Tech Rep Ser 1971:469.

25 World Health Organisation. Arterial hypertension. WHO Tech Rep Ser 1978:628.

26 Gribbin B, Pickering TG, Sleight P, Peto R. Effect of age and high blood pressure on baroreflex sensitivity in man. Circ Res 1971;29:424-31.

27 Wollner L, McCarthy ST, Soper NDW, Macy DJ. Failure of cerebral autoregulation as a cause of brain dysfunction in the elderly. $\mathrm{Br}$ Med $\mathcal{f}$ 1979;i:1117-8.
28 Strandgaard S, Olesen J, Skinhoi $E$, Lassen NA. Autorequlation of brain circulation in severe arterial hypertension. Br Med f 1973;i:507-10.

29 Strandgaard S. Autoregulation of cerebral blood flow in hypertensive patients. The modifying influence of prolonged antihypertensive treatment on the tolerance to acute, drug-induced hypotension. Circulation 1976;53:720-7.

$30 \mathrm{Kety}$ SS. Human cerebral blood flow and oxygen consumption as related to ageing. $\mathcal{F}$ Chronic Dis 1956;3:478-86.

31 Thomas DJ, Zilkha E, Redmond S, et al. An intravenous ${ }^{133}$ xenon-clearance technique for measuring cerebral blood flow. I Neurol Sci 1979;40:53-63

32 Davis SM, Ackerman RH, Correia JA, et al. Cerebral blood flow and cerebrovascular $\mathrm{CO}_{2}$ reactivity in stroke-age normal controls. Neurology 1983;33:391-9.

33 Thomas DJ, Marshall J, Russell RW, et al. Effect of haematocrit on cerebral blood-flow in man. Lancet 1977;ii:941-3.

34 Brown MM, Marshall J. Regulation of cerebral blood flow in response to changes in blood viscosity. Lancet 1985; ;:604-9.

35 Kendell RE, Marshall J. Role of hypotension in the genesis of transient focal cerebral ischaemic attacks. BrMed 7 1963;ii:344-8.

36 Torvik A, Skullerud K. How often are brain infarcts caused by hypotensive episodes? Stroke 1976;7:255-7.

37 Adams JH, Brierley B, Connor RCR, Treip CS. The effects of systemic hypotension upon the human brain, clinical and neuropathological observations in 11 cases. Brain 1966;89:235-80.

38 Hurwitz H. Predisposing factors in adverse reactions to drugs. Br Med F 1969;i:536-9.

39 Williams BO. Use and misuse of diuretics in the elderly. Prescribers fournal 1985;25:51-6.

(Accepted 11 fuly 1986)

\title{
Determinants and importance of stress hyperglycaemia in non-diabetic patients with myocardial infarction
}

\author{
G A OSWALD, C C T SMITH, D J BETTERIDGE, J S YUDKIN
}

\begin{abstract}
Determinants of plasma glucose concentrations were studied in patients on admission to hospital with confirmed acute myocardial infarction but without previous glucose intolerance as evidenced by raised concentrations of glycosylated haemoglobin $\left(\mathbf{H b A}_{\mathrm{lc}}\right)$. Mortality in hospital increased significantly with increasing plasma concentrations of glucose in patients with both normal $(\mathbf{p}<0.0001, n=311)$ and borderline $(\mathbf{p}<0.02, n=70)$ concentrations of $\mathbf{H b A}_{\mathrm{lc}}$. There was a weak relation between plasma glucose concentrations and infarct size as estimated by peak aspartate transaminase activity in both $\mathbf{H b A}_{\mathrm{lc}}$ groups $\left(\mathbf{r}_{\mathbf{s}}=\right.$ $0.26, n=101$ and $r_{s}=0.41, n=35$ respectively). A correlation was found between adrenaline and plasma glucose concentrations $(r=0.47, n=27)$ and cortisol and plasma glucose concentrations $(r=0.75, n=19)$, but the relation of plasma noradrenaline and plasma glucose suggested a threshold effect. Concentrations of adrenaline, but not those of noradrenaline or cortisol, correlated with infarct size as measured both by peak aspartate transaminase activity and cumulative release of creatine kinase MB isoenzyme. Multiple regression analysis showed that concentrations of cortisol, adrenaline, and noradrenaline (but not the concentration of $\mathbf{H b A}_{\mathrm{lc}}$, infarct size, or age) are the main determinants of plasma glucose concentration measured in non-diabetic patients when admitted to hospital after acute myocardial infarction.
\end{abstract}

Academic Unit of Diabetes and Endocrinology, University College and Middlesex School of Medicine, Whittington Hospital, London N19 5NF G A OSWALD, MD, MRCP, research fellow in diabetes

J S YUDKIN, MD, MRCP, consultant and senior lecturer in diabetes

Department of Medicine of the University College and Middlesex School of Medicine, London WC1E 6JJ

C C T SMITH, MSC, PHD, research fellow and honorary lecturer in biochemistry D J BETTERIDGE, PHD, MRCP, senior lecturer

Correspondence and requests for reprints to: Dr Yudkin.

\section{Introduction}

The reasons for excessive mortality in diabetic patients with acute myocardial infarction remain undetermined. The potentially reversible metabolic disequilibriums that accompany acute myocardial infarction in diabetics may be responsible, ${ }^{1}$ although this is a difficult hypothesis to test. ${ }^{2}$ A relation has, however, been described in patients with acute myocardial infarction between hyperglycaemia on admission and the development of cardiogenic shock independent of the state of premorbid glucose tolerance. ${ }^{3}$ Thus hyperglycaemia alone might possibly contribute to poor outcome in patients both with and without known diabetes. We tested this hypothesis in non-diabetic patients, in whom other factors peculiar to diabetes mellitus which may contribute to outcome after acute myocardial infarction, such as the existence of a specific diabetic heart muscle disease ${ }^{4}$ or abnormal rheology, ${ }^{5}$ are not present. The interrelations of hyperglycaemia on admission to hospital, infarct size, hormonal response to stress, and outcome in a group of patients with acute myocardial infarction, but without evidence of premorbid undiagnosed diabetes, were investigated.

\section{Methods}

The study group consisted of 397 patients, without known diabetes mellitus, admitted consecutively to the Whittington Hospital with acute myocardial infarction confirmed by the World Health Orgnisation's criteria. ${ }^{6}$ Figure 1 shows the design of the study and composition of the patient subgroups. In all patients venous blood was taken immediately or shortly after their admission for determining concentrations of $\mathrm{HbA}_{\mathrm{cc}}$. Patients were classified as previously described ${ }^{3}$ into clearly normal (group $1, \mathrm{HbA}_{\mathrm{lc}}<6.9 \%$ ), borderline (group 2, $\mathrm{HbA}_{\mathrm{lc}} 6 \cdot 9-7 \cdot 8 \%$ ), or clearly abnormal (group 3, $\mathrm{HbA}_{\mathrm{lc}}>7 \cdot 8 \%$ ) groups. Seventeen patients had concentrations of $\mathrm{HbA}_{\mathrm{tc}}$ falling into group 3 , which we have found to be indicative of undiagnosed diabetes, ${ }^{36 a}$ and were considered no further.

STUDY 1: RELATION BETWEEN PLASMA GLUCOSE AND HBA $\mathrm{A}_{\mathrm{lc}}$ CONCENTRATIONS AND OUTCOME

Of the 380 patients without diabetes, samples for plasma glucose measurement were taken from 236 on their admission to hospital before 


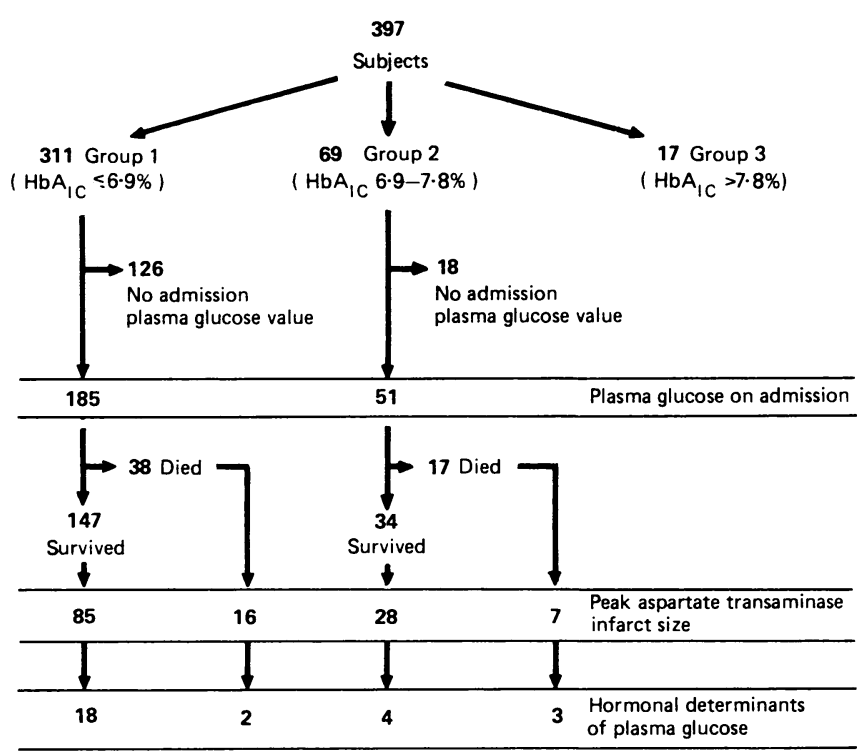

FIG 1-Patient numbers and study design.

$\alpha$ or $\beta$ agonistic agents were administered or glucose infused. The median time of sampling from onset of symptoms was nine hours (range 1-24 hours). In this subgroup the relation between plasma glucose, $\mathrm{HbA}_{1 \mathrm{c}}$, and outcome was studied.

STUDY 2: RELATION BETWEEN PLASMA GLUCOSE CONCENTRATION AND SIZE OF INFARCT

This relation was studied in a selected subgroup. Criteria for inclusion comprised, firstly, availability of a plasma glucose value taken on admission to hospital and, secondly, survival for at least 48 hours to allow assessment of the size of the infarct by peak aspartate transaminase activity. One hundred and one consecutive patients from group 1 and 35 consecutive patients from group 2 who fulfilled these criteria were included.

\section{STUDY 3: HORMONAL DETERMINANTS OF HYPERGLYCAEMIA}

The hormonal response to acute myocardial infarction was studied in a subgroup of 29 patients, not known to be diabetic, selected by virtue of admission to the coronary care unit (where the special arrangements for the collection and preparation of samples had been made), and satisfying the criteria outlined above. When patients arrived in the coronary care unit and they had been given adequate analgesia, venous blood was taken for determining $\mathrm{HbA}_{\mathrm{lc}}$, plasma glucose, cortisol, and catecholamine concentrations through a previously inserted cannula. Median time from onset of symptoms to sampling was 11 hours (range 1-23). Blood for catecholamine estimation was taken into tubes of cooled lithium heparin, which were subsequently transferred to an ice water slurry. The plasma was separated promptly at $+4^{\circ} \mathrm{C}$ and frozen at $-20^{\circ} \mathrm{C}$ until assay. Two of these patients died before the size of infarct could be determined by peak aspartate transaminase activity and were considered no further. None of the remaining 27 patients had concentrations of $\mathrm{HbA}_{\mathrm{lc}}$ indicating undiagnosed diabetes, ${ }^{362} 20$ having clearly normal concentrations and seven borderline concentrations. In total six patients developed cardiogenic shock, of whom five died. Results of cortisol concentrations were not available for seven patients of the total studied.

\section{ASSAY METHODS}

$\mathrm{HbA}_{\mathrm{lc}}$ was determined, free of labile adducts, using an isoelectric focusing technique. ${ }^{7}$ Size of infarct was calculated by two methods. In all patients studied the peak aspartate transaminase activity, measured on admission and daily for at least 48 hours after acute myocardial infarction, was taken as an estimate of myocardial necrosis. Aspartate transaminase activity was measured in the routine clinical chemistry laboratory of the Whittington Hospital, using a commercial kit (AST Optimised, BCL, Lewes, Sussex). Peak aspartate transaminase activity correlates well with more specific measures of infarct size ${ }^{8}$ as well as with both long term and short term mortality after acute myocardial infarction, ${ }^{9}$ and as such is a reasonable estimate of the extent of myocardial necrosis. In 19 of the 27 patients in the study of hormone concentrations and outcome infarct size was further estimated by cumulative release of creatine kinase MB isoenzyme using the method of Sobel and Shell ${ }^{10}$ as adapted by Boyle $e t$ al. ${ }^{11}$ Sampling for creatine kinase MB was performed when patients were admitted and subsequently every eight hours for at least 48 hours. The creatine kinase MB isoenzyme activity was determined by an immunological method (BCL, Lewes, Sussex) that uses an antibody to inhibit the activity of the $\mathrm{BB}$ fraction. In 28 patients, both diabetic and non-diabetic, in whom estimates of both peak aspartate transaminase activity and cumulative creatine kinase $M B$ isoenzyme were performed we found a moderate correlation between the estimates of infarct size $(r=0.67, p<0.001)$, similar to the correlation previously described. ${ }^{8}$

Catecholamines (adrenaline and noradrenaline) were determined by high performance liquid chromatography with electrochemical detection. ${ }^{12}$ Cortisol was estimated by radioimmunoassay using a commercial kit (Amerlex, Amersham International, United Kingdom).

\section{STATISTICAL METHODS}

Statistical analysis was by least squares regression, Spearman's rank correlation $\left(r_{s}\right)$, Mann-Whitney U test, $\chi^{2}$ test with Yates's correction where appropriate, Kendall $\tau \mathrm{c}$ for trend, analysis of variance, logistic regression, and multiple linear regression analysis. The analysis was performed with a statistical package for the social sciences program. Logarithmic transformation was used when variables showed a positively skewed distribution, and a quadratic term was used for analysing exponential relations. Ninety five per cent confidence intervals are given for proportions, differences in means or proportions, and $\beta$ or $B$ values in logistic and multiple regression analyses, although in these latter cases it is recognised that the effects are not independent. For logistic regression analysis the $95 \%$ confidence interval is also presented as the upper and lower ends of the relative risk ratio for a certain change in the independent variable.

\section{Results}

\section{SELECTION BIAS}

There was no significant difference between the ages or gender of the patients in any of the three studies and those not included. Their mean age was 65.36 years (difference in mean ages 1.93 years, $95 \%$ confidence interval $(\mathrm{CI})-0.45$ to 4.31 years in study $1 ; 0.91$ years, $95 \% \mathrm{CI}-0.88$ to 2.70 years in study $2 ; 0.51$ years, $95 \% \mathrm{CI}-4.06$ to 5.08 years in study $3 ; \mathrm{p}>0.1$ in all cases). The proportion of women overall was $26.8 \%$ (the difference in proportion of women was $8 \cdot 6 \%, 95 \% \mathrm{CI}-1$ to $18 \%$ in study $1 ; 4 \cdot 0 \%, 95 \% \mathrm{CI}$ -5 to $13 \%$ in study $2 ; 7 \cdot 0 \%, 95 \% \mathrm{CI}-11$ to $25 \%$ in study $3 ; \mathrm{p}>0 \cdot 1$ in all cases). The mortality of patients sampled for plasma glucose when admitted $(22 \cdot 8 \%)$ was similar to that of patients not sampled $(27 \cdot 3 \%)$ (difference in proportion $4 \cdot 5 \%, 95 \% \mathrm{CI}-4 \cdot 5$ to $13 \cdot 5 \%, \mathrm{p}>0 \cdot 3$ ). The mortality of patients without estimates of peak aspartate transaminase $(29 \cdot 1 \%)$ was, however, substantially greater than that of patients for whom such estimates were available $(16 \cdot 2 \%$ ) (difference in proportion $12.9 \%$, $95 \%$ CI $4 \cdot 4$ to $21 \cdot 4 \%$, $\mathrm{p}<0.005$ ) because survival for 48 hours was a prerequisite for inclusion in this study.

\section{STUDY 1: RELATION BETWEEN PLASMA GLUCOSE, HBA ${ }_{\mathrm{Ic}}$, AND} OUTCOME

Table I shows the distribution of mortality between normoglycaemic patients (plasma glucose $<8 \mathrm{mmol} / \mathrm{l}(<144 \mathrm{mg} / 100 \mathrm{ml})$ ), patients with moderate hyperglycaemia (plasma glucose $8-11 \mathrm{mmol} / 1$ (144-198 mg/100 $\mathrm{ml})$ ), and those with appreciable hyperglycaemia (plasma glucose $>11$ $\mathrm{mmol} / \mathrm{l}(>198 \mathrm{mg} / 100 \mathrm{ml}))$. There was a highly significant $\left(\chi^{2}=29 \cdot 27\right.$ $\mathrm{p}<0.001$; Kendall $\tau$ c $0.285, \mathrm{p}<0.001)$ stepwise increase in mortality with increasing plasma glucose values in the patients with clearly norma concentrations of $\mathrm{HbA}_{\mathrm{lc}}$ (group 1). In patients in group 2, no deaths were recorded among the 12 patients with plasma glucose concentrations less than $8 \mathrm{mmol} / \mathrm{l}(<144 \mathrm{mg} / 100 \mathrm{ml})$, but there was substantial mortality in the patients whose plasma glucose concentration exceeded $8 \mathrm{mmol} / 1\left(\chi^{2}=8 \cdot 04\right.$ $\mathrm{p}<0.01$; Kendall $\tau \mathrm{c} 0.357, \mathrm{p}<0.01)$. Analysis of the data using stepwise logistic regression with outcome as the dependent variable, and age, sex plasma glucose, and peak aspartate transaminase activity as the independent variables, showed that the major determinants of mortality in group 1 were age $\left(\chi^{2}=16 \cdot 6, p<0 \cdot 001, \beta=0 \cdot 139 \pm 0 \cdot 039 ; 95 \%\right.$ CI for risk ratio for five year change $1.36-2 \cdot 92)$ and plasma glucose $\left(\chi^{2}=13.6, p<0.002, \beta=0.303 \pm 0.099\right.$ $95 \%$ CI for risk ratio for $5 \mathrm{mmol} / 1(90 \mathrm{mg} / 100 \mathrm{ml})$ change $1 \cdot 71$ to $12 \cdot 03)$. Peak aspartate transaminase activity failed to reach significance in this model $\left(\chi^{2}=\right.$ $3.3, p=0.07, \beta=0.0026 \pm 0.0014 ; 95 \% \mathrm{CI}$ for risk ratio for $100 \mathrm{IU}$ change 
0.98 to 1.73 ), probably because early death precluded estimation of this enzyme for 48 hours. In a similar analysis in patients in group 2 no variable reached standard levels of significance $(95 \% \mathrm{CI}$ in risk ratios for age 0.69 to $2 \cdot 00$; plasma glucose $0 \cdot 11-3 \cdot 37$; aspartate transaminase activity $0 \cdot 85-2 \cdot 18$; all $\mathrm{p}>0 \cdot 1$ ).

\section{STUDY 2: INFARCT SIZE, PLASMA GLUCOSE, AND OUTCOME}

Using non-parametric correlation analysis we found significant relations between plasma glucose concentrations on admission to hospital and peak aspartate transaminase activity in both groups $\left(r_{s}=0 \cdot 26, p<0 \cdot 005, n=101\right.$ in group 1 (fig 2); $r_{s}=0.41, p<0.01, n=35$ in group 2). Figure 2 shows that despite this positive relation, there were several patients with appreciable hyperglycaemia and fairly low levels of enzyme release; seven patients had plasma glucose concentrations of more than $11 \mathrm{mmol} / \mathrm{l}$ but were in the lower half of distribution of aspartate transaminase activity. Similarly in group 2 three patients had plasma glucose concentrations greater than $11 \mathrm{mmol} / \mathrm{l}$ but were in the lower half of distribution of aspartate transaminase activity. Table II shows the characteristics of these 10 patients; eight of them either developed left ventricular failure or died, predominantly from cardiogenic

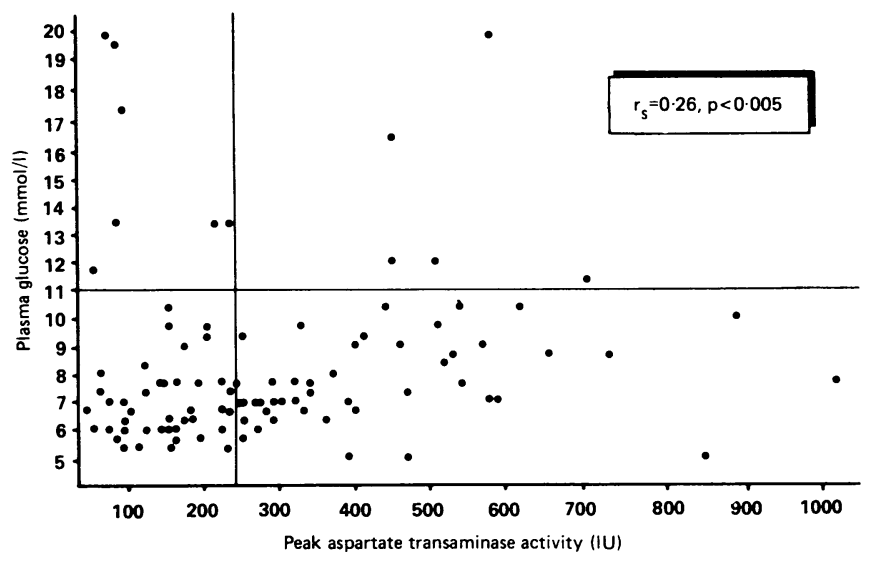

FIG 2-Plot of plasma glucose (on admission) and peak aspartate transaminase in 101 consecutive patients from group 1. Lines indicate the median for aspartate transaminase activity and a plasma concentration of glucose of $11 \mathrm{mmol} / \mathrm{l}$.

TABLE I-Patient details and mortality by $\mathrm{HbA}_{\mathrm{Ic}}$ group and by plasma glucose concentrations on admission

\begin{tabular}{lcc}
\hline & Group 1 & Group 2 \\
\hline No & 311 & 69 \\
Age (SD) & $64 \cdot 9(11 \cdot 9)$ & $67 \cdot 6(9 \cdot 4)$ \\
No (\%) of women & $86(27 \cdot 7)$ & $15(21 \cdot 8)$ \\
No (\%) who died with plasma glucose concentrations (mmol/) & & \\
$\quad$ on admission of: & $12 / 112(10 \cdot 7) \mathrm{CI} 5 \cdot 0-16 \cdot 4 \%$ & $0 / 12(0)$ \\
$<8$ & $13 / 52(25 \cdot 0) \mathrm{CI} 12 \cdot 2 \cdot 36 \cdot 8 \%$ & $8 / 20(40 \cdot 0) \mathrm{CI} 18 \cdot 5 \cdot 61 \cdot 5 \%$ \\
$8-11$ & $13 / 21(61 \cdot 9) \mathrm{CI} 41 \cdot 1-82 \cdot 7 \%$ & $9 / 19(47 \cdot 4) \mathrm{CI} 25 \cdot 0-69 \cdot 8 \%$ \\
$>11$ & $29 \cdot 27 \mathrm{p}<0 \cdot 001$ & $8 \cdot 04 \mathrm{p}<0 \cdot 02$ \\
$\chi^{2}$ & $0 \cdot 285 \mathrm{p}<0 \cdot 001$ & $0 \cdot 357 \mathrm{p}<0 \cdot 01$ \\
Kendall $\tau-\mathrm{c}$ & $36 / 126(28 \cdot 6) \mathrm{CI} 20 \cdot 7-36 \cdot 5 \%$ & $3 / 18(16 \cdot 7 \%) \mathrm{CI} 0-33 \cdot 9 \%$ \\
No $(\%)$ who died with no plasma glucose estimation & & \\
\hline
\end{tabular}

Conversion: SI to traditional units_Glucose: $1 \mathrm{mmol} / \mathrm{l} \approx 18 \mathrm{mg} / 100 \mathrm{ml}$.

TABLE II-Patients with severe hyperglycaemia and low peak aspartate transaminase activity

\begin{tabular}{|c|c|c|c|c|c|}
\hline $\begin{array}{l}\text { Case } \\
\text { No }\end{array}$ & Sex & $\begin{array}{c}\text { Age } \\
\text { (years) }\end{array}$ & $\begin{array}{l}\text { Plasma } \\
\text { glucose } \\
(\mathrm{mmol} / \mathrm{l})\end{array}$ & $\begin{array}{c}\text { Peak } \\
\text { aspartate } \\
\text { transaminase } \\
(\mathrm{IU} / \mathrm{l})\end{array}$ & Course \\
\hline \multicolumn{6}{|c|}{ Group 1} \\
\hline 1 & $\mathbf{M}$ & 54 & $12 \cdot 0$ & 50 & Uncomplicated \\
\hline 2 & $\mathrm{~F}$ & 74 & $17 \cdot 4$ & 96 & Left ventricular failure \\
\hline 3 & $\mathrm{~F}$ & 78 & $13 \cdot 6$ & 230 & Left ventricular failure \\
\hline 4 & $\mathbf{F}$ & 80 & $13 \cdot 6$ & 210 & Died, cardiogenic shock \\
\hline 5 & $\mathbf{F}$ & 63 & $16 \cdot 3$ & 171 & Died, ventricular fibrillation \\
\hline 6 & $\mathrm{~F}$ & 75 & $13 \cdot 4$ & 81 & Died, cardiogenic shock \\
\hline 7 & $\mathrm{~F}$ & 68 & $19 \cdot 7$ & 84 & Died, cardiogenic shock \\
\hline \multicolumn{6}{|c|}{ Group 2} \\
\hline 1 & $\mathbf{M}$ & 68 & $14 \cdot 7$ & 310 & Died, cardiogenic shock \\
\hline 2 & $\mathbf{M}$ & 67 & $18 \cdot 6$ & 230 & Left ventricular failure \\
\hline 3 & $\mathbf{M}$ & 78 & $16 \cdot 3$ & 102 & Uncomplicated \\
\hline
\end{tabular}

shock. In case 5 (group 1) hyperglycaemia, measured when the patient was first admitted, may have been related to a cardiac arrest that occurred out of hospital; this patient never regained consciousness, and hyperglycaemia in these circumstances has been linked to poor prognosis for recovery of consciousness by an unknown mechanism. ${ }^{13}$

STUDY 3: HORMONAL AND OTHER DETERMINANTS OF HYPERGLYCAEMIA

In 27 patients the relation between concentrations of cortisol and catecholamines and the size of the infarct were studied. Using logarithmically transformed data concentrations of plasma glucose correlated with the size of the infarct as measured by cumulative creatine kinase MB enzyme release, with cortisol, adrenaline, and noradrenaline (table III). Although the relation of both adrenaline and cortisol with plasma glucose concentrations appeared to be linear, that of noradrenaline with glucose appeared to be non-

TABLE III-Correlation coefficient of hormones, glycosylated haemoglobin, cumulative creatine kinase MB isoenzyme, and plasma glucose. Data are logarithmically transformed except $H b A_{1 c}$ and age. Values shown are linear correlation coefficients $(r)$ with their significance in parentheses

\begin{tabular}{|c|c|c|c|c|c|c|c|}
\hline & $\begin{array}{l}\text { Plasma glucose } \\
\text { on admission } \\
(\mathbf{n}=27)\end{array}$ & $\begin{array}{l}\text { Cortisol } \\
(\mathbf{n}=20)\end{array}$ & $\begin{array}{c}\text { Adrenaline } \\
(\mathbf{n}=27)\end{array}$ & $\begin{array}{c}\text { Noradrenaline } \\
\quad(\mathbf{n}=27)\end{array}$ & $\begin{array}{c}\text { Cumulative isoenzyme } \\
\text { release } \\
(n=19)\end{array}$ & $\underset{(\mathbf{n}=27)}{\mathrm{HbA}_{\mathrm{lc}}}$ & $\begin{array}{c}\text { Age } \\
(\mathbf{n}=27)\end{array}$ \\
\hline Cortisol & $\begin{array}{c}0.75 \\
(<0.001)\end{array}$ & & & & & & \\
\hline Adrenaline & $\begin{array}{c}0.47 \\
(<0.01)\end{array}$ & $\begin{array}{c}0 \cdot 20 \\
(0 \cdot 20)\end{array}$ & & & & & \\
\hline Noradrenaline & $\begin{array}{c}0.54^{\star} \\
(<0.002)\end{array}$ & $\begin{array}{c}0.34 \\
(0 \cdot 07)\end{array}$ & $\begin{array}{c}0.52 \\
(<0.005)\end{array}$ & & & & \\
\hline Cumulative isoenzyme release & $\begin{array}{c}0.65 \\
(<0.001)\end{array}$ & $\begin{array}{c}0.39 \\
(0.051)\end{array}$ & $\begin{array}{c}0.48 \\
(<0.02)\end{array}$ & $\begin{array}{c}-0.07 \\
(0.38)\end{array}$ & & & \\
\hline $\mathrm{HbA}_{\mathrm{lc}}$ & $\begin{array}{c}0.57 \\
(<0.001)\end{array}$ & $\begin{array}{c}0.53 \\
(<0.01)\end{array}$ & $\begin{array}{c}0.49 \\
(<0.005)\end{array}$ & $\begin{array}{c}0.44 \\
(<0.02)\end{array}$ & $\begin{array}{c}0.25 \\
(0.15)\end{array}$ & & \\
\hline Age & $\begin{array}{c}0.12 \\
(0.27)\end{array}$ & $\begin{array}{c}0.49 \\
(<0.02)\end{array}$ & $\begin{array}{l}0.07 \\
(0.36)\end{array}$ & $\begin{array}{c}0.08 \\
(0.34)\end{array}$ & $\begin{array}{c}-0.09 \\
(0.35)\end{array}$ & $\begin{array}{c}0.44 \\
(<0.02)\end{array}$ & \\
\hline
\end{tabular}

* The correlation between noradrenaline and plasma glucose uses a quadratic term (log noradrenaline $\left.)^{2}\right)$. 

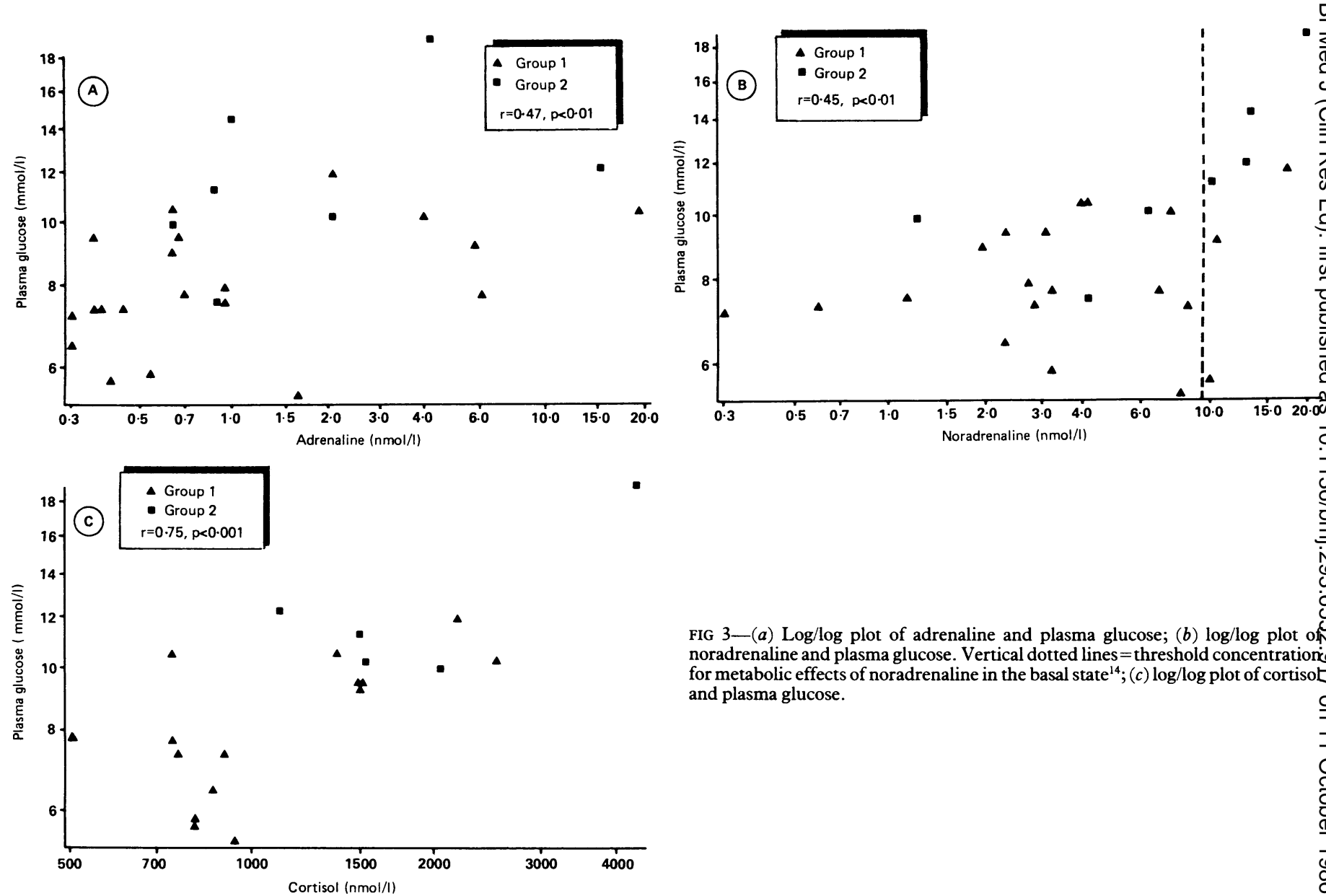

linear and was compatible with a threshold effect (fig 3 ). When patients whose concentrations of noradrenaline exceeded $9 \mathrm{nmol} / \mathrm{l}(15 \cdot 2 \mathrm{ng} / 100 \mathrm{ml})$ were excluded, this being the concentration at which noradrenaline has metabolic effects ${ }^{14}$ this relation disappeared. For this reason further analysis of the relation between noradrenaline and plasma glucose concentrations was performed using a quadratic term (logarithm of noradrenaline+ (logarithm of noradrenaline) $)^{2}$.

The determinants of released catecholamine and cortisol early in the course of acute myocardial infarction were sought. A correlation was found between adrenaline and the size of the infarct as assessed by cumulative creatine kinase isoenzyme MB values (fig 4), but no significant correlation was present between either noradrenaline or cortisol and the size of infarct assessed by cumulative creatine kinase MB. Analysis of variance showed that noradrenaline was significantly related to age $(p=0.04)$ but not to cumulative creatine kinase MB values $(p=0.91)$ or gender $(p=0.93)$.

Six determinants of plasma glucose (noradrenaline, adrenaline, cortisol, age, cumulative creatine kinase $\mathrm{MB}$, and $\mathrm{HbA}_{\mathrm{lc}}$ ) were then further

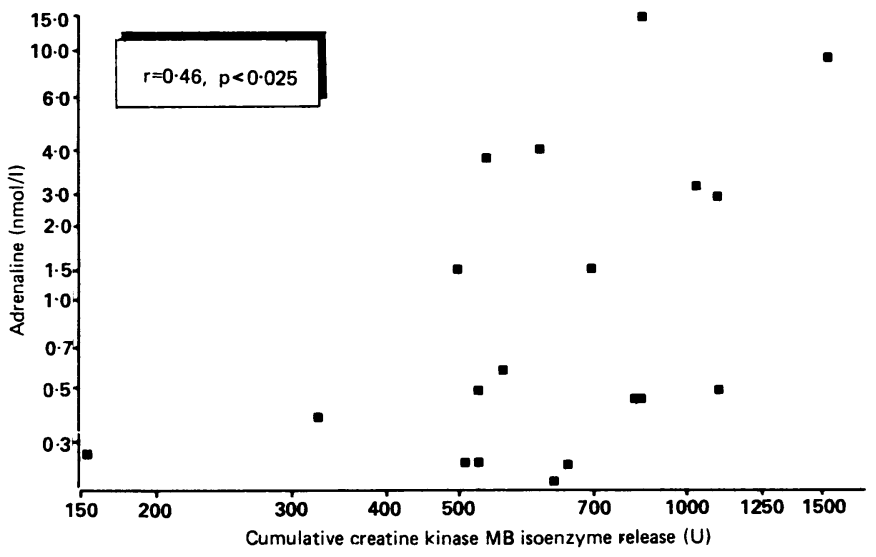

FIG $4-\mathrm{Log} / \log$ plot of adrenaline against size of infarct assessed by cumulative release of creatine kinase $\mathrm{MB}$ isoenzyme.

assessed in a multiple linear regression analysis of patients in whom infarct size had been accurately assessed by determining cumulative creatine kinase $\mathrm{MB}$ activity. Cortisol $\left(\mathrm{F}_{1,17}=22 \cdot 86, \mathrm{~B}=0.415 \pm 0.084, \mathrm{p}<0.001\right)$ was the principal significant determinant of plasma glucose (multiple $r^{2}=0.56$ ) and both adrenaline $\left(F_{1,16}=6.21, B=0.086 \pm 0.028, p=0.03\right.$, multiple $\left.r^{2}=0.73\right)$ D and noradrenaline $\left(F_{2,15}=4 \cdot 50, B=0 \cdot 060 \pm 0.018 \text { for (log noradrenaline }\right)^{2}$, $\mathrm{p}<0.05$, multiple $\mathrm{r}^{2}=0.69$ ) provided similar contributions. There was noO additional contribution from $\mathrm{HbA}_{\mathrm{lc}}\left(\mathrm{F}_{1,13}=1 \cdot 20, \mathrm{~B}=0.023 \pm 0.021, \mathrm{p}>0.2,3\right.$ multiple $r^{2}=0 \cdot 76$ ). Moreover, adding cumulative creatine kinase MB did not? significantly increase the explained proportion of the variance of plasma? glucose $\left(F_{1,12}=2.95, B=0.250 \pm 0.145, p>0.1\right.$, multiple $\left.r^{2}=0.81\right)$. Age was not a significant determinant of plasma glucose concentration in this $\operatorname{model}\left(\mathrm{F}_{1,11}=0.03, \mathrm{~B}=0.003 \pm 0.007, \mathrm{p}>0.8\right)$.

Figure 5 shows the distribution of the concentrations of catecholamine $\frac{\sigma}{-}$ and cortisol on admission in all 27 patients studied. The patients with plasma-. glucose concentrations over $11 \mathrm{mmol} / \mathrm{l}$ are indicated in the figure. These fiveo patients had the highest concentrations of noradrenaline, but concentrations of cortisol and adrenaline were more widely distributed. Four of theseo patients developed cardiogenic shock.

\section{Discussion}

Hyperglycaemia on admission to hospital, independent of the state of premorbid glucose tolerance, has been shown to be linked to응 the development of cardiogenic shock in non-diabetic patients witho acute myocardial infarction. ${ }^{3}$ In this study we have shown a further $\mathbb{\varnothing}$ relation between increasing plasma glucose concentration and death? in hospital from acute myocardial infarction in patients highly? unlikely to have undiagnosed diabetes mellitus. Indeed, over half the patients with normal or borderline $\mathrm{HbA}_{\mathrm{lc}}$ and plasma glucose $\stackrel{乛}{?}$ concentrations greater than $11 \mathrm{mmol} / 1$ died in hospital from their $\mathbb{Q}$ acute myocardial infarction.

The relation between enzymatically determined infarct size and plasma glucose concentration confirms that stress hyperglycaemia iso a real phenomenon in non-diabetic patients with acute myocardial infarction, and that poor outcome in such patients predominantly? 

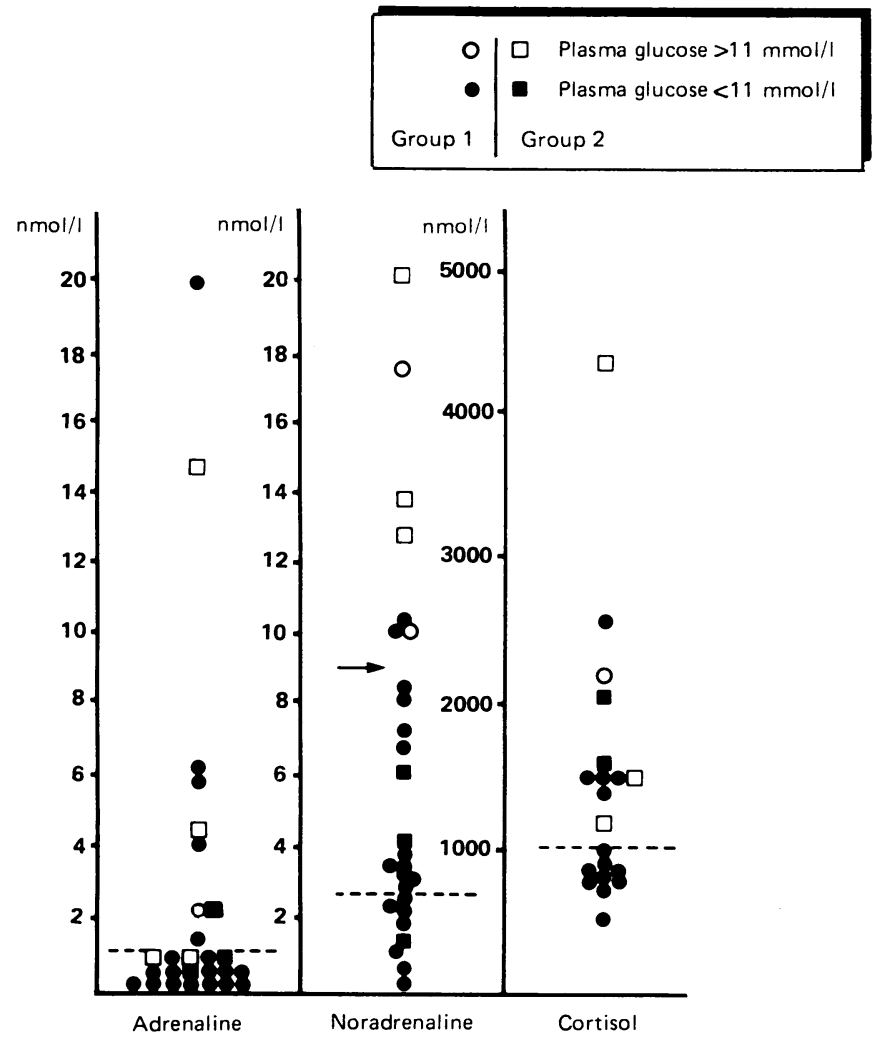

FIG 5-Distribution of hormone results obtained on admission in 27 patients surviving to have the size of their infarct assessed by peak aspartate transaminase activity. Dotted lines=upper limits of normal, arrow=level beyond which noradrenaline has measurable metabolic changes in the basal state. ${ }^{14}$

Conversion: SI to traditional units-Adrenaline: $1 \mathrm{nmol} / \mathrm{l} \approx 18.3 \mathrm{ng} / 100 \mathrm{ml}$. Noradrenaline: $1 \mathrm{nmol} / \mathrm{l} \approx 16.92 \mathrm{ng} / 100 \mathrm{ml}$. Cortisol: $1 \mu \mathrm{mol} / \mathrm{l} \approx 35 \cdot 71 \mu \mathrm{g} / 100 \mathrm{ml}$. Glucose: $1 \mathrm{mmol} / \mathrm{l} \approx 18 \mathrm{mg} / 100 \mathrm{ml}$.

reflects the clinical course of the extent of underlying infarction. ${ }^{9}$ We showed a correlation between plasma concentrations of adrenaline in the early stages of infarction and the size of the infarct. Hyperglycaemia measured on admission in most non-diabetic patients with acute myocardial infarction is determined both by the extent of infarction, mainly through the secretion of adrenaline, and through secretion of other stress hormones that are independent of infarct size. In experimental myocardial infarction it has been suggested that the stimulus to adrenaline release is a reflex arising from receptors at the site and boundary of the infarct. ${ }^{15}$ The relation of plasma concentrations of adrenaline early in the course of infarction to infarct size in the patients we studied is compatible with a similar mechanism existing in man.

Hyperglycaemia is associated with poor outcome even when age and size of infarct are taken into consideration. Several patients were identified as having an infarct of moderate size, as estimated by peak aspartate transaminase activity, but with appreciable hyperglycaemia, and these subjects had a poor prognosis, with their cause of death being mainly pump failure. Such patients probably do not have undiagnosed diabetes, but possibly hyperglycaemia may be contributing to, rather than consequent on, their poor outcome. Patients with plasma concentrations of glucose over $11 \mathrm{mmol} / \mathrm{l}$ who were further investigated in study 3 , however, showed high concentrations of both noradrenaline and cortisol early in the course of acute myocardial infarction, but no relation between these hormone concentrations and infarct size was found. Thus in some patients hyperglycaemia appears related to an excess stress hormone response, independent of the extent of infarction.

In patients with chronic stable heart failure noradrenaline concentrations have been found to be a sensitive and specific indicator of the degree of myocardial dysfunction. ${ }^{16} 17$ Severe myocardial dysfunction in the presence of acute myocardial infarction of apparent modest extent may have been precipitated by infarction superimposed on an already diseased myocardium, perhaps resulting from previous acute myocardial infarction or from diffuse ischaemia.

Although plasma catecholamine concentrations fluctuate in the period after admission to hospital,${ }^{18}$ these concentrations generally remain raised for up to 48 hours. ${ }^{19}$ We have shown, using multiple regression analysis, that despite the range of times between onset of symptoms and sampling in this study, adrenaline, noradrenaline, and cortisol concentrations, together with $\mathrm{HbA}_{\mathrm{lc}}$ values and the size of the infarct, account for roughly $80 \%$ of the variation in plasma glucose values.

Other workers have found relations between the extent of infarction and the catecholamine response early in the course of acute myocardial infarction. ${ }^{20}{ }^{21}$ Our results, however, differ from those of Benedict and Grahame-Smith, ${ }^{20}$ who found relations between concentrations of noradrenaline, but not of adrenaline, and the size of infarcts. Previous studies concerning the relations between the size of infarcts and plasma cortisol concentrations have also shown good correlations, which we have not confirmed. ${ }^{22-24}$ These discrepancies may arise from the different subject populations; in the quoted studies most patients developed cardiogenic shock and were found to have both extensive infarction and very high concentrations of noradrenaline and cortisol, whereas in our study most patients had uncomplicated acute myocardial infarction.

Several groups have attempted to define the cause of hyperglycaemia after acute myocardial infarction. A recent study found that plasma glucose in subjects after acute myocardial infarction was related to concentrations of adrenaline but not noradrenaline..$^{25} \mathrm{~A}$ previous study described a relation between noradrenaline concentrations and fasting plasma glucose concentrations taken shortly after infarction, ${ }^{26}$ but this is perhaps surprising in view of the concentrations of noradrenaline in that study, which were well below those at which metabolic effects become apparent. ${ }^{14}$ One study has also shown a relation between plasma cortisol concentrations and those of fasting blood glucose. ${ }^{24}$ The mechanism of stress hyperglycaemia in patients after acute myocardial infarction may be similar to that shown in dogs, ${ }^{27}$ where different hormones relating to stress have been found to act synergistically both to increase glucose production and to reduce clearance. In our study the contribution of infarct size to plasma glucose concentration on admission was insignificant after allowing for the effects of cortisol and catecholamines, but other workers have suggested that glucagon may also contribute to hyperglycaemia..$^{28}$

In conclusion, hyperglycaemia seen on admission in non-diabetic patients with acute myocardial infarction is an important prognostic indicator, and is mainly determined by raised concentrations of catecholamines and cortisol. These in turn are either a response to extensive infarction or associated with severe myocardial dysfunction. We found no evidence in our study to suggest that hyperglycaemia was contributory to, rather than purely resultant on, poor outcome. By inference, perhaps hyperglycaemia in diabetic patients with acute myocardial infarction may also not be causally associated with poor outcome, although studies of the effect of induction of normoglycaemia on the clinical course of diabetic patients with acute myocardial infarction ${ }^{229}{ }^{30}$ would be necessary to test this hypothesis.

We thank the medical and nursing staff of the admission ward and coronary care unit, without whose help this study would not have been possible. We are grateful to Dr Brian Newman, department of statistics, University College London, for statistical advice, and we also wish to thank Dan Wilsher for help with the statistical analyses and Gill Brown for expert secretarial help. GAO was supported by Novo Laboratories Ltd.

\section{References}

1 Gwilt DJ. Why do diabetics die after myocardial infarction? Practical Diabetes 1984;1(2):36-9. 2 Husband DJ, Alberti KGMM, Julian DG. Methods for the control of diabetes after acute myocardial infarction. Diabetes Care 1985;8:261-7.

myocardial infarction. Diabetes Care 1985;8:261-7.
Oswald G, Corcoran S, Yudkin JS. Prevalence and risks of hyperglycaemia and undiagnosed diabetes in patients with acute myocardial infarction. Lancet 1984;i:1264-7.

4 Shapiro LM, Howat AP, Calter MM. Left ventricular function in diabetes mellitus. 1-Methodology, and prevalence and spectrum of abnormalities. Br Heart $\mathcal{F}$ 1981;45:122-8.
. 5 McMillan DE. The effect of diabetes on blood flow properties. Diabetes 1983;32(suppl 2):56-63. 6 World Health Organisation. Regional Office for Europe. Public health in Europe 5 . Annex 1 Copenhagen: World Health Organisation, 1976. (Myocardial infarction community registers.) 
6a Oswald GA, Yudkin JS. The relative contribution of undiagnosed diabetes mellitus and "stress" to hyperglycaemia following acute myocardial infarction. Diabetic Medicine (in press)

7 Mortensen HB. Quantitative determination of hemoglobin Alc by thin layer iso-electric focusing. f Chromatogr 1980;182:325-33.

8 Witteveen SAGJ, Hemker HC, Hollaar L, Hermens WTh. Quantitation of infarct size in man by means of plasma enzyme levels. Br Heart f 1975;37:795-803.

9 Thompson PL, Fletcher EE, Katavatis V. Enzymatic indices of myocardial necrosis: influence on short and long term prognosis after myocardial infarction. Circulation 1979;59:113-9.

10 Sobel BE, Shell WE. Serum enzyme determinations in the diagnosis and assessment of myocardial infarction. Circulation 1972;45:471-82.

11 Boyle DMcC, Barber JM, McIlmoyle EL, et al. Effect of very early intervention with metoprolol on myocardial infarct size. Br Heart $\mathcal{f}$ 1983;49:229-33.

12 Smith CCT, Curtis LD, Delamothe AP, Prixchard BNC, Betteridge DJ. The distribution of catecholamines between platelets and plasma in normal human subjects. Clin Sci 1985;69:1-6. 13 Longstreth WT, Diehr P, Inui TS. Prediction of awakening after out-of-hospital cardiac arrest. N Engl f Med 1983;308:1378-82.

14 Silverberg AB, Shah SD, Haymond MW, Cryer PE. Norepinephrine: hormone and neurotransmitter in man. Am $\mathcal{J}$ Physiol 1978;234:E252-6.

15 Staszewska-Barczak J. The reflex stimulation of catecholamine secretion during the acute stage of myocardial infarction in the dog. Clin Sci 1971;41:419-39.

16 Cohn JN, Levine TB, Olivari MT, et al. Plasma norepinephrine as a guide to prognosis in patients with chronic congestive heart failure. $N$ Engl f Med 1984;311:819-23.

17 Thomas JA, Marks BH. Plasma nor-epinephrine in congestive heart failure. Am $\mathcal{f}$ Cardiol 1978;41:233-43.

18 Karlsberg RP, Cryer PE, Roberts R. Serial plasma catecholamine response early in the course of clinical acute myocardial infarction: relationship to infarct extent and mortality. Am Heart $\mathcal{f}$

19 Videbak J, Christensen NJ, Sterndoff B. Serial determination of plasma catecholamines in myocardial infarction. Circulation 1972;46:846-55.
20 Benedict CR, Grahame-Smith DG. Plasma adrenaline and noradrenaline concentrations and dopamine- $\beta$-hydroxylase activity in myocardial infarction with and without cardiogenic she $k$. BrHeart F 1979;42:214-20.

21 Jewitt DE, Mercer CJ, Reid D, Valori C, Thomas M, Shillingford JP. Free noradrenaline adrenaline excretion in relation to the development of cardiac arrhythmias and heart failuo in

patients with acute myocardial infarction. Lancet 1969;i:635-41.
22 Bailey RR, Abernathy MH, Beaven DW. Adrenocortical response to the stress of an aente

23 Prakash R, Parmley WW, Horvat M, Swan HJC. Serum cortisol, plasma free fatty acids, $\overline{\text { Gind }}$ urinary catecholamines as indicators of complications in acute myocardial infarction. Circulation

24 Burckhardt P, Felber J-P, Perret C. Adrenocortical, insulin and metabolic changes in response to

acute myocardial infarction. Helvetica Medica Acta 1972;36:277-93.
25 Little RA, Frayn KN, Randall PE, et al. Plasma catecholamines in patients with acute myoca infarction and in cardiac arrest. Qf Med 1985;54:133-40.

26 Christensen NJ, Videbak J. Plasma catecholamines and carbohydrate metabolism in patients acute myocardial infarction. $\mathcal{f}$ Clin Invest 1974;54:278-86.

27 Eigler N, Sacca L, Sherwin RL. Synergistic interactions of physiologic increments of glucagen, epinephrine, and cortisol in the dog. A model for stress-induced hyperglycemia. $\mathcal{F}$ Clin I 1979;63:114-23.

28 Willerson JT, Hutcheson DR, Leshin SJ, Faloona GR, Unger RH. Serum glucagon and insalin levels and their relationship to blood glucose values in patients with acute myocardial infarçon and acute coronary insufficiency. Am $\mathcal{F}$ Med 1974;57:747-53.

29 Gwilt DJ, Petri M, Lamb P, Nattrass M, Pentecost BL. Effect of intravenous insulin infusiomon mortality among diabetic patients after myocardial infarction. Br Heart $\mathcal{f} 1984 ; 51: 626-31$. O

30 Clark RS, English M, McNeill GP, Newton RW. Effect of intravenous infusion of insuling in diabetics with acute myocardial infarction. Br Med F 1985;291:303-5.

(Accepted 16 fuly 1986)

\section{SHORT REPORTS}

\section{Thrombotic microangiopathy and acute renal failure associated with arteriography}

Acute renal failure after administration of contrast media has been well documented. In the late 1950s a change from earlier contrast media to salts of diatrizoate was thought to have curtailed this problem, but a review in 1978 reported 75 well documented cases of acute renal failure after use of newer contrast media. ${ }^{1}$ We report on a man with a well functioning renal transplant in whom thrombotic microangiopathy caused acute renal failure after aortofemoral angiography. This form of acute renal failure induced by a radiocontrast agent has not been recognised previously.

\section{Case report}

A 59 year old man with renal failure due to analgesic nephropathy started haemodialysis in 1973. In 1979 he underwent successful cadaveric renal transplantation, and the serum creatinine concentration remained normal $(0 \cdot 10$ $0 \cdot 12 \mathrm{mmol} / 1(1 \cdot 1-1.3 \mathrm{mg} / 100 \mathrm{ml}))$ for six years. In March 1985 he presented with severe bilateral intermittent claudication and underwent angiography before a left femoral-popliteal bypass operation. After angiography, in which he was given $70 \mathrm{ml}$ of $65 \%$ meglumine diatrizoate intravenously, his renal function deteriorated acutely, the serum creatinine concentration rising from 0.12 to $0.22 \mathrm{mmol} / \mathrm{l}$ $(1 \cdot 3$ to $2 \cdot 4 \mathrm{mg} / 100 \mathrm{ml})$ and falling again to $0 \cdot 11-0 \cdot 12 \mathrm{mmol} / \mathrm{l}$. His urine output remained normal during this episode.

He was readmitted in June for angiography on the right side because of worsening symptoms and distal ulceration. On admission creatinine concentration was $0 \cdot 11 \mathrm{mmol} / 1(1 \cdot 1 \mathrm{mg} / 100 \mathrm{ml})$. He was well hydrated on the day of angiography. The next day, however, the serum creatinine concentration rose to $0.27 \mathrm{mmol} / 1(3.0 \mathrm{mg} / 100 \mathrm{ml})$, and it continued to rise until the seventh day after angiography, when he required haemodialysis because of uraemic symptoms. Over the same period the haemoglobin concentration fell from $127 \mathrm{~g} / 1$ to $86 \mathrm{~g} / \mathrm{l}$ and the platelet count from $314 \times 10^{9} / 1$ to $73 \times 10^{9} / 1$. A blood film showed spherocytes and fragmented red blood cells. The bilirubin concentration peaked at $36 \mu \mathrm{mol} / 1(2 \cdot 1 \mathrm{mg} / 100 \mathrm{ml})($ normal $<19 \mu \mathrm{mol} / 1(<1 \cdot 1 \mathrm{mg} / 100 \mathrm{ml}))$. Urine output fell from $5950 \mathrm{ml}$ on the day of angiography to $540 \mathrm{ml}$ four days later (figure). Urine microscopy showed $10 \times 10^{9}$ glomerular red cells/l and numerous renal tubular epithelial cells. Renal biopsy on day 6 showed occlusion of many glomerular capillaries by fibrin thrombi, while others contained polymorphs. The appearances were those of thrombotic microangiopathy. Acute tubular necrosis and some mild features of chronic vascular rejection were also evident.

Plasma exchange with four litres of reconstituted plasma protein precipitate was begun as soon as the result of the biopsy was known and was continued daily for four days and then on alternate days for three weeks. The serum creatinine concentration fell rapidly to $0.14 \mathrm{mmol} / 1(1.5 \mathrm{mg} / 100 \mathrm{ml})$, and urine volumes returned to normal. In spite of the good initial response to plasma exchange renal function deteriorated gradually and three months later biopsy showed diffuse double contours in glomerular capillaries and continuing activity resembling chronic microangiopathy on electron microscopy.

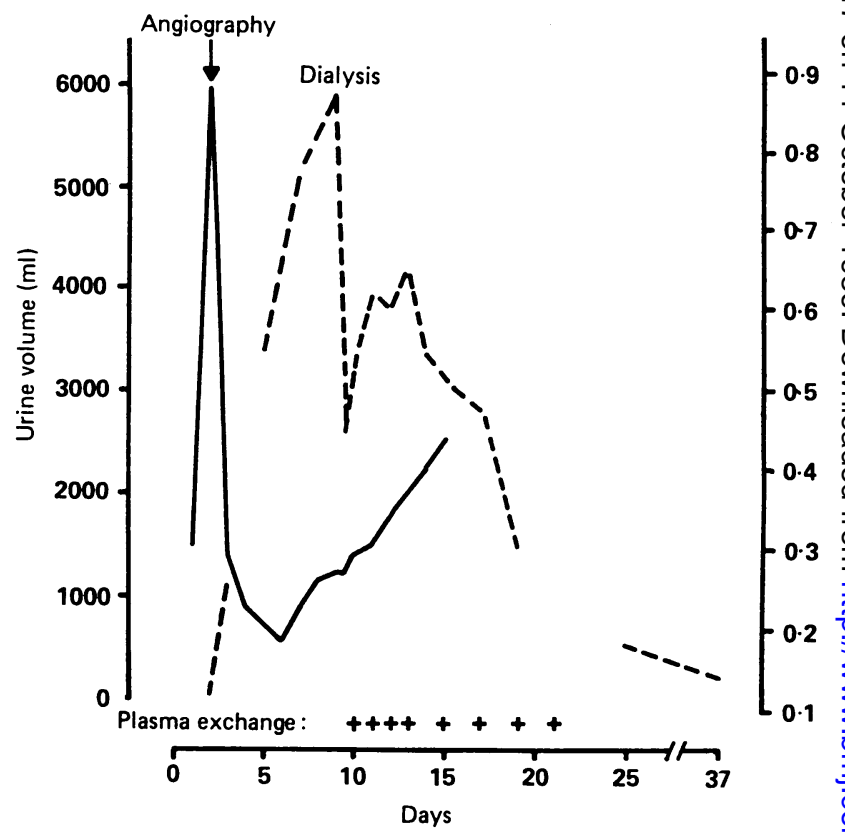

Urine volume (-) and serum creatinine concentrations (----) after angiography.

\section{Comment}

The mechanism of acute renal failure after administration of contrast media was initially ascribed to acute tubular necrosis ${ }^{2}$ or acute interst fal nephritis. ${ }^{3}$ To our knowledge we report a previously unrecognised meehanism of acute renal failure after arteriography-namely, thromberic microangiopathy. The outlook for patients with acute renal failure resuleing from thrombotic microangiopathy is poor without treatment.

Although thrombotic microangiopathy can result from acute gaft rejection, this is unlikely to occur so long after transplantation. Fluid loading and high urine output, which are recommended to prevent acute ral failure after administration of contrast media, were not effective in this patient. Two mechanisms might have led to the diffuse thrombi in glomeghli in this case. In our view the most likely is that atheromatous emboli were dislodged into the renal artery during angiography. Atheromatous materal has been shown to activate complement in vitro, ${ }^{4}$ and infusion of atheromatous material into the carotid artery in rats leads to diffuse fibrin thrombi in glomeruli. Alternatively, the activation of complement by contrast medium ${ }^{5}$ could have precipitated the thrombotic microangiopathy. 